Please do not remove this page

RMIT

UNIVERSITY

\title{
Behavioural change starts in the family: The role of family communication and implications for social marketing
}

Aleti, Torgeir; Brennan, Linda-Marie

https://researchrepository.rmit.edu.au/esploro/outputs/9921858216701341/filesAndLinks?institution=61RMIT_INST\&index=null

Aleti, T., \& Brennan, L.-M. (2011). Behavioural change starts in the family: The role of family communication and implications for social marketing. Journal of Nonprofit \& Public Sector Marketing, 23(4), 367-386. https://doi.org/10.1080/10495142.2011.623526

Document Version: Accepted Manuscript

Published Version: https://doi.org/10.1080/10495142.2011.623526

Repository homepage: https://researchrepository.rmit.edu.au

Copyright (C) Taylor \& Francis Group, LLC

Downloaded On 2023/04/26 18:44:24 +1000

Please do not remove this page 
Thank you for downloading this document from the RMIT Research Repository.

The RMIT Research Repository is an open access database showcasing the research outputs of RMIT University researchers.

RMIT Research Repository: http://researchbank.rmit.edu.au/

\section{Citation:}

Watne, T and Brennan, L 2011, 'Behavioural change starts in the family: The role of family communication and implications for social marketing', Journal of Nonprofit \& Public Sector Marketing, vol. 23, no. 4, pp. 367-386.

See this record in the RMIT Research Repository at:

http://researchbank.rmit.edu.au/view/rmit:13943

Version: Accepted Manuscript

Copyright Statement: (c) Taylor \& Francis Group, LLC

Link to Published Version:

http://dx.doi.org/10.1080/10495142.2011.623526 


\title{
Behavioural change starts in the family: The role of family communication and implications for social marketing
}

(Shortened title; Behavioural change starts in the family.)

Torgeir Watne (corresponding author)

Faculty of Business and Law

Victoria University

Ballarat Road, Footscray

PO Box 14428

Melbourne, VIC 8001

Torgeir.Watne@vu.edu.au

$+61399195367$

Linda Brennan

School of Media and Communication

RMIT University

GPO Box 2476

Melbourne, VIC 3001

Linda.brennan@rmit.edu.au

$+61399252842$

\begin{abstract}
This paper investigates reciprocal consumer socialisation in families with a particular focus on the influence young adults above 18 years living at home have over their parents. A dyadic method of analysis was used to determine the level of influence young people have on the decision making of their parents with regard to the consumption of environmentally sustainable products. Our research shows that parents are not only influenced by their adolescent children, but that they are much more likely to take their children's advice when the family foster open issue-based communication patterns with respect for others. Our findings show that when the parents initially encourage their children to develop their own opinions and at the same time uphold the family hierarchy, they are much more likely to take their children's advice as well. In addition, our results show that single parents are more influenced by their children than dual parent families. Finally, we found that fathers do not communicate well with their sons when it comes to environmentally sustainable products. Fathers are more likely to listen to their daughters. For social marketers seeking to address issues of sustainable consumption, these are important findings. Strategies aimed at young people could be useful well beyond the sphere of the child. While young people are notoriously difficult to find in the modern communications landscape, they can be found with clever social marketing and media strategies.
\end{abstract}

\section{Key words}

Consumer socialisation, environmentally sustainable products, family decision making 


\section{Background}

Understanding how to save the environment is a complex and daunting task for most people (Sexton, 2006). In mid July 2011 a googlescholar search for the terms 'environmentalism' and 'social marketing' returned 2,030 citations and/or articles since 2010. Clearly this is a 'hot topic'. However, while hot, the topic is potentially so enormous that consumers do not actually know what to do. In such cases, people are known to find expertise in other people that they can rely on while making a decision (Alba \& Hutchinson, 1987; Belch, Krentler, \& Willis-flurry, 2005; Jinkook \& Jinsook, 2005). The most (seemingly) reliable source of expertise is often from those closest to the consumer (Chang, Chen, \& Somerville, 2003; Davis, 1976; Douglas, 1983; Szybillo, 1979) - the family. However, families rarely debate consumption decisions. They often get used to how the other thinks and adjust their decision making according to the deep knowledge of each other that grows over time. That is, through a process of (consumer) socialisation. In social marketing, we need to understand the consumer decision-making process in order to develop strategies for behaviour change. How families make decisions about consumption of environmental products is therefore important to creating innovative social marketing strategies.

Family communication patterns (FCP) is often used as a measure of consumer socialisation (i.e. how parents socialise their children as consumers) (Chan \& McNeal, 2006; Moschis \& Churchill, 1978; Rose, Dalakas, \& Kropp, 2003). An open and issue-based (concept oriented) family communication can enhance reciprocity with regards to consumer socialisation in the family (Watne, 2010). When parents enable concept-oriented communication patterns in the family, they are also more inclined to consider their children's opinions with regards to their own consumption. This is true even when the children are young adults above 18 yours living at home (Watne 2010). We propose that this may also include parent's likelihood to learn from their 18 year old children with regards to environmentally sustainable products. In order to address this, we need to look at consumer socialisation in the family from both the parent's and children's point of view. Many social marketing campaigns are addressed at the household. Often, the parent(s) are the key informant for such strategies. However, we argue that adolescents are active decision makers regarding their uses (and abuses) of environmental products. This paper presents an innovation in social marketing research: the examination of the influence of adolescents in the household.

It is our contention that there is a conceptual difference between primary and secondary socialisation. The former mainly takes place during childhood, while the latter takes place in adult life and builds on the individual's primary socialisation (Berger and Luckmann, 1967). Understanding the differences between primary and secondary consumer socialisation is important in any area where consumption patterns have changed between generations. Arguably, children in 2011 have more programs at school about environmentally sustainable products than their parents had. Thus, their primary socialisation with regards to this category may differ. In the following sections, we outline the conceptual differences between primary and secondary socialisation and how reciprocity in family communication can enhance the family's understanding of environmentally sustainable products. 


\section{Consumer Socialisation}

The majority of consumer socialisation research has been focused on children (Ekström, 2006; John, 1999; Moschis, 1987), even though definitions of socialisation clearly recognise that it is a life-long process (Bandura, 1977; Berger \& Luckmann, 1967; Brim, 1966). That is, socialisation processes continue well beyond a person's childhood. Berger and Luckmann (1967) distinguished between primary and secondary socialisation. Primary socialisation takes place as a child; while secondary socialisation takes place after childhood (e.g. shame for nudity comes from primary socialisation, adopting an adequate dress code depends on secondary socialisation). Consumer socialisation of children can thus be seen as primary because it involves children's initial development of skills, knowledge and attitudes to function in the marketplace (cf. Ward, 1974). Furthermore, consumer socialisation of adults is concerned with the adjustment of these initial skills, knowledge and attitudes in order to adapt to new situations and can therefore be seen as secondary (cf. Mathur, 1999; Pettersson, Olsson, \& Fjellström, 2004). Thus, when adults learn about new issues concerning the environment (e.g. need the need to save water); they will attempt to add this knowledge to an already established framework. It becomes problematic for social marketers when these established frameworks do not exist. In such cases, because of influences external to the family, the child might be the most knowledgeable in the household.

Secondary socialisation involves processes that induct an already socialised individual into new sectors of the objective world of his or her' society (Berger \& Luckmann, 1967). From a consumer socialisation perspective, secondary socialisation would logically include adaptation to marketplace changes through social interaction (Mathur, 1999). It can be regarded as 'secondary consumer socialisation' if an adult consumer updates skills, knowledge or attitude to better function when the marketplace is changing. In the case of environmental sustainability, the rapidly changing situation leads to an inability to effectively engage with the issues without personal expertise (Frame \& Newton, 2007). In addition, expertise can be vicarious; that is, derived from others. In the main, when seeking expertise in a family, expert power comes from the person with the most knowledge of the domain (Cialdini, 1993). With regard to sustainable consumption, the expert is often one of the children, if only because education regarding these issues is a relatively recent phenomenon in generational terms (Ballantyne, Connell, \& Fien, 1998). Currently, not much is known about how children influence their parents in terms of purchasing environmentally sustainable products.

However, we do know that consumer socialisation researchers have suggested that children play an important role in socialisation of their parents (e.g. Easterling, Miller, \& Weinberger, 1995; Mathur, 1999; Moschis, 1987). The consumer socialisation approach for both primary and secondary socialisation suggests that consumption is learned through social interaction with external sources; commonly referred to as 'socialisation agents' (Chan \& McNeal, 2006; John, 1999; Taeho, 2005). Agents of socialisation are people and groups that influence a change in the learners' selfconcepts, emotions, attitudes, and behaviour (Bandura, 1969, 1977). Most research on consumer socialisation has focused on the family as the main socialisation agent (see for example Dotson \& Hyatt, 2000; Lachance, Beaudoin, \& Robitaille, 2003; Taeho, 2005). This is commensurate with the social marketing research domain in as much as it incorporates a consideration of the social interactions that lead to individual 
behaviours. Descriptive norms primarily come from the family and the near social context.

An agent of socialisation will have some control over rewards and punishments for the learner (Brim, 1966; Moschis, 1987). This means that the learner adjusts behaviour, knowledge and attitude with accordance to the agent, based on rewards and punishments. Within family decision-making situations, both children and adults learn and adjust; therefore there is a need to include reciprocity of socialisation with regard to consumer socialisation in a family framework. In order to understand how parents and children in the same family influence each other about environmentally sustainable products, we need to include an investigation of the parent's primary socialisation of the child, as well as the possibility of secondary socialisation from child to parent.

\section{Reciprocal Consumer Socialisation}

Children's influence on the consumption decisions of their parents varies by the nature of the product, the stage of the decision process, and the nature of the child (Mangleburg, 1990). Often, the parent's initial and ongoing socialisation of the child is related to the influence the child have on the parent. This effect has been labelled reciprocal consumer socialisation (Sorce, Loomis, \& Tyler, 1989). Reciprocal socialisation is a socialisation process that is bidirectional; children socialise parents just as parents socialise children (Watne, 2010). In order for children to function as socialisation agents, they need to provide positive learning outcomes for their parents. For social marketers, the challenge becomes creating the positive touch points for children to share with their parents.

Additionally, the reciprocity of consumer socialisation in families also indicates a need to study the relationship between primary socialisation of the child and secondary socialisation of the parent. It has been argued that little is known about the latter and that we do not know much about how parents learn from their children (Ekström, 2006; Moschis, 1987). Such a reciprocal view is implemented by focusing on the level of agreement between parent and child when it comes to the parent's initial primary socialisation of the child, as well as secondary socialisation from child to parent. This view of reciprocal consumer socialisation is represented in Table 1.

Table 1: Dyadic data sources in reciprocal consumer socialisation

\begin{tabular}{|llll|} 
Source & Unit of Analysis & Locus of measurement & Property being measured \\
\hline Child & Individual & $\begin{array}{l}\text { Perceptions of SELF } \\
\text { Perceptions of OTHER person }\end{array}$ & $\begin{array}{l}\text { Personal characteristics } \\
\text { Perceptions }\end{array}$ \\
\hline Parent & Individual & Perceptions of SELF & Personal characteristics \\
& & Perceptions of OTHER person & Perceptions \\
\hline Dyad & Both child and & SELF and OTHER & Agreement \\
& parent & & Similarity \\
& & & Complementarity \\
& & Reciprocity \\
& & Mutuality \\
& & Interdependence \\
\hline
\end{tabular}

Table 1 shows that there are various sources of data when it comes to child and parent dyads. Firstly, there is the child and their parent as individuals, as well as the two combined to generate data with regard to the dyad. Thus, there are three possible sources of information with regard to the family. The third type of data, dyadic data, will show the responses of both child and parent in relation to each other. As a result 
of this, dyadic data can show the social marketer the impact of the relationship's properties on family decision-making. It is especially useful for examining properties such as power, norms, rules and codes of conduct (Anderson, 1994). These properties necessarily involve a consideration of the impact of 'other'. That is, a person's view of them is formed in conjunction with others and they are not formed by the individual in isolation of the social domain.

One of the key foundations for socialisation is (of course) that of the family. Families have different ways of being; they interact, play and communicate differently according to unwritten but powerful 'rules'. The way people within families communicate has been the subject of much research in marketing. However, as at the writing of this paper, the social marketing domain does not appear to have invested much research effort into understanding family communication patterns.

\section{Family Communication}

Family communication patterns about consumption are a fundamental aspect of consumer socialisation (Rose, Bush, \& Kahle, 1998); they provide a way of assessing the interaction between parents, children, and their consumption environment (Chan $\&$ McNeal, 2003). Family communication patterns have often been used to measure how parents (primarily) socialise their children as consumers (as mentioned before). Family communication is an important factor in reciprocal socialisation because it can indicate whether there is a connection between how the children are socialised by the parent (primary socialisation) and the influence the child has on the parent (secondary socialisation). Watne (2010) demonstrated a link between family communication patterns (FCP) and the family's attitude towards children as socialisation agents for the parents. Thus, FCP is instrumental with regards to the influence children have over their parent's consumption because is sets the framework for secondary socialisation from child to parent.

Current conceptualisations of family communication patterns have their roots in general models of communication and socialisation: Newcomb (1953) viewed communication as the co-orientation of two persons (A and B) to one another and toward some external topic of issues (X). Following Newcomb's (1953) model; socialisation researchers McLeod and Chaffee (1972) developed a typology of parent/child communication structures and patterns. Family communication patterns were later adjusted into a measure of communication about consumption by McLeod and Chaffee's students (cf. Moschis, 1987).

The original conceptualisation of family communication was that it comprised two dimensions: socio-oriented and concept-oriented. The socio-oriented dimension measures vertical or relationship-oriented (social) patterns of communication, while concept orientation measures issue-oriented (concept) patterns of communication.

The socio-orientation dimension measures vertical or relationship-oriented patterns of communication. In these patterns of communication, the emphasis is on parental control and children's deference to authority (Chan \& McNeal, 2003). This dimension is analogous to the types of social power because it suggests that one party is superior to the other in the relationship. This dimension stresses Newcomb's A-B relationships; where person A tells person B what their attitude should be towards X (Moschis, 1987). The communication is also designed to foster harmonious and 
pleasant social relationships at home (Moschis, 1987) in terms of children learning to have respect for their parents. In the context of consumption, socio-oriented parents maintain control and restrict their children's purchasing (Moschis, 1987).

The emphasis of concept-oriented communication is to encourage children to establish an independent evaluation of an issue (Rose, 1998; Chan, 2003). This pattern focuses on positive constraints that help a child to develop his or her own view about the world, stressing Newcomb's A-X relationships (Moschis, 1987). The parents might, for example, encourage the child to weigh all alternatives before making a decision or expose the child to controversy - either by differing openly on an issue or by discussing it with guests at home (McLeod \& Chaffee, 1972). With regard to family purchase processes, it is known that the more concept-oriented the family is (i.e. the more freely communicative the parents and child), the less disagreement exists regarding adolescents' influence (Foxman, Tansuhaj, \& Ekström, 1989) and the children are likely to have a greater impact on family purchase decisions (Rose, Boush, \& Shoham, 2002).

The two dimensions addressed here are not assumed to be mutually exclusive; some families might value both and some families might have a lack of communication about consumption altogether. Thus, the two family communication patterns dimensions of parent child communication (socio-oriented and concept-oriented) produce a fourfold typology of family communication patterns (expressed in cooriented terms using Newcomb's (1953) A-B-X paradigm): laissez-faire, protective, pluralistic, and consensual patterns of communication (McLeod \& Chaffee, 1972).

\begin{tabular}{|c|c|c|}
\hline & 0 & $\mathbf{n}$ \\
\hline & Low & High \\
\hline 总 & $\begin{array}{l}\text { Laissez-Faire } \\
\begin{array}{l}\text { - } \quad \text { Little communication with children } \\
\text { - } \quad \text { Little parental impact on consumption }\end{array}\end{array}$ & $\begin{array}{ll}\text { Protective } \\
\text { - Stress vertical relationships } \\
\text { - } \\
\begin{array}{l}\text { Obedience and social harmony } \\
\text { outside information }\end{array} \\
\end{array}$ \\
\hline 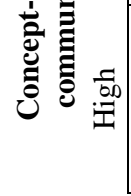 & $\begin{array}{cl}\text { Pluralistic } \\
\text { - Stress horizontal relationships } \\
\text { - } \quad \text { Issue-oriented communication } \\
\text { - } \quad \text { Children are encouraged to explore } \\
\quad \text { ideas and express opinions } \\
\end{array}$ & $\begin{array}{ll}\text { Consensual } \\
\qquad \quad \text { Maintain control over children's } \\
\quad \text { consumption } \\
\text { - } \quad \begin{array}{l}\text { Frequent communication with children } \\
\text { about consumption }\end{array} \\
\end{array}$ \\
\hline
\end{tabular}

Figure 1: Family Communication Patterns (source: Chan and McNeal 2003; Moschis 1987).

Laissez-faire families (low concept-oriented, low socio-oriented) lack emphasis on both kinds of communication; there is little parent-child communication in these families (Moschis, 1987). Laissez-faire parents engage in relatively low levels of communication with their children and hence have the least influence in shaping their children's consumption patterns (Chan, 2003; Rose, 1998). These families represent an extreme in freedom and lack of interest, much socialisation takes place outside the family system (Niemi, 1988). In laissez-faire families parents may, for example, let the child decide what the family needs without much interference. Since there is a lack of interest in shaping the child's consumption pattern, the child may educate themselves while the parent remains ignorant or learns about the product on their own or through different channels. 
Protective families (low concept-oriented, high socio-oriented) stress obedience and social harmony in their communication; there is little debate over conceptual matters (Moschis, 1987). These families tend to emphasise vertical relationships, obedience, and social harmony, and limit their children's exposure to outside information such as television advertising (Rose, 1998). Protective parents do not encourage children to develop independent preferences (Chan \& McNeal, 2003), this may be realised at the expense of open communication (Niemi, 1988). Further, a protective communication pattern based on parental control might be based on various degrees on narcissism from the parent's side because protective parents are overly concerned with controlling the child's behaviour in order to accommodate their own needs (Rappoport, 2005). Further, this may result in the child wanting to rebel against their parent and doing the opposite of what they are told to do (Rappoport, 2005).

On the other hand, pluralistic families (high concept-oriented, low socio-oriented) encourage open communication and discussion of ideas without insisting on obedience to authority; the child is encouraged to explore new ideas and to express their own opinions without fear of retaliation. The emphasis in this communication structure appears to be mutuality of respect and interests (Moschis, 1987), even though this may entail the risk of conflict (Niemi, 1988). Pluralistic parents tend to stress issue-oriented communication and maintain a relatively horizontal parent-child relationship (Chan \& McNeal, 2003; Rose, et al., 1998).

Lastly, consensual families (high concept-oriented, high socio-oriented) stress both types of communication; the child is encouraged to take interest in the world of ideas but to do so without disturbing the family's hierarchy of opinion (Moschis, 1987). Consensual parents engage in issue-oriented communication, encourage expression of ideas, but at the same time maintain parental control, and stress the importance of considering others (Chan \& McNeal, 2003; Rose, et al., 1998). The consensual family allows children to think independently but at the same time it strives for internal harmony (Niemi, 1988).

With regard to consumption, some families emphasise parental control and children's deference to authority (socio-oriented), while other families emphasise the child's development of an independent evaluation of an issue (concept-oriented) (McLeod \& Chaffee, 1972). A focus on parental control might discourage the child from influencing the parent, at the same time as the parent might be unwilling to take the child's advice. For example, parents might tell the child they cannot purchase certain things, which might make the child unwilling to assist the parent in purchasing. Further, the parent may need to feel 'in control' and will thus not take advice from the child.

It is known that family communication patterns are related to the family's attitude towards children as socialisation agents when it comes to small high-tech and computer related products (Watne, 2010). This relationship may also be true when it comes to environmentally sustainable products. While patterns of family communication sets the framework for how parents (primarily) socialise their children, the family's attitude towards the child as an agent to socialisation for the parent sets the framework for how children (secondarily) socialise the parent. Thus, for social marketers, it is important to understand how these patterns work. If the child has more knowledge about the environment, will the parent listen? Could social 
marketing strategies be developed based on this type of communication and socialisation?

Family communication patterns may also differ by family structure. For example, single parent families make decisions differently to dual parent families (Ahuja, Capella, \& Taylor, 1998). In addition, fathers and mothers communicate differently with their children and about different topics (Chen, 2008). While this is not surprising for anyone with children, we are not sure of how this dynamic works in the social marketing or environmental context.

\section{Attitude towards children as socialisation agents}

In addition to family communication dynamics, the outcome of bilateral communication is reciprocal socialisation and (therefore) how children influence their parents. For our research purposes, how children may influence their parents' consumer behaviour is here assumed to be related to the dyads attitude towards Children as Socialisation Agents (CSA) for their parents. Attitude can be defined as any subjective belief or evaluation associated with an issue (VandenBos, 2007). Parent's and children's attitude towards CSA consists of their subjective believe about how children influence parent's consumer behaviour. Watne (2010) demonstrated a relationship between attitude towards CSA and concept-oriented family communication. The results established that there is a relationship between open and issue-based communication from the parent's side and the parent's willingness to learn from the child. In Watne's (2010) research, attitude towards CSA is used as a measure of secondary socialisation from child to parent while FCP as described above is used to measure primary socialisation from parent to child. Consequently, the relationship between the two illustrates reciprocal consumer socialisation. For this paper, we examined these concepts in relation to environmental products with a view to developing more appropriately targeted social marketing strategies.

\section{Hypothesis}

Previous research has suggested that both family size and gender may have an impact on how children influence their parents (Chavda, Haley, \& Dunn, 2005; Hahlo, 1999; Watne, Lobo, \& Brennan, 2011). Thus, for this research we propose that gender of parent and child, as well as family size; have an impact on the level of agreement about attitude towards children as socialisation agents. One-parent families may be more close-knit; thus, we suggest the following hypothesis:

H1 $1_{\mathbf{a}}$ : The level of agreement about attitude towards children as socialisation agents for their parents is stronger in single parent families than in dual parent families.

$\mathbf{H 1}_{\mathbf{b}}$ : The attitude towards children as socialisation agents for their parents is more prominent in single parent families than in dual parent families.

When it comes to gender of parents and children it is difficult to suggest any particular direction. However, we still suspect that there may be gender differences. For example, Watne, Lobo and Brennan (2011) found that sons had a large influence over their mothers while daughters had no influence over their fathers when it came to computer related products. Since we are not sure about the gender relationship when it comes to environmentally sustainable products, we suggest: 
H2 $2_{\mathrm{a}}$ : The level of agreement about attitude towards children as socialisation agents for their parents varies depending on gender.

$\mathbf{H} \mathbf{2}_{\mathbf{b}}$ : Gender plays a significant role in families' attitude towards children as socialisation agents for their parent with regards to environmentally sustainable products.

For this study, we wanted to see if parents would be persuaded by their children with regard to consumption of environmentally sustainable products and whether family communicating patterns had any impact on the influence. Such a relationship may assist social marketers in developing strategies for how families can communicate more effectively and learn from each other about environmentally sustainable products. Based on the above discussion about communication patterns, we suggest that consensual families will have the most positive attitude towards children as socialisation agents while laissez-faire families will be the least positive:

$\mathbf{H 3}_{\mathbf{a}}$ : Consensual families have the most positive attitude towards children as socialisation agents for their parents.

$\mathbf{H 3}_{\mathbf{b}}$ : Laissez-faire families have the least positive attitude towards children as socialisation agents for their parents.

\section{Method}

The dyads were asked questions about their attitude towards children as socialisation agents (CSA) for their parents, as well as their perception of family communication patterns. All scale items were measured on seven point Likert-type scales. The construct for the attitude towards CSA was measured with a 6-item scale, while family communication patterns were measured on 10-item scale (5 items for conceptoriented and 5 items for socio-oriented).

Attitude towards CSA for their parents were measured based on the classical primary components of an attitude, i.e., cognitive, affective-evaluative, and conative factors (e.g. Jacoby, 1971; Quester \& Lim, 2003). These three components of attitudes were similar; hence they were combined to develop one scale. Thus, 6 items relating to parents as learners, or children as agents such as "I get useful information from my child about environmentally sustainable products" and "I influence my parent to buy the right environmentally sustainable products." were developed for this purpose. Family communication patterns were measured with the scale conceptualised by Moschis (1987). Reliability was tested in terms of internal consistencies with Cronbach's Alpha (Cronbach, 1951). The Cronbach's Alpha values for all items ranged between .80 and .91 which is considered as being reliable (Churchill \& Iacobucci, 2005; Hair, Black, Babin, \& Anderson, 2010).

When analysing the data, the dyad were used as unit of analysis. This technique facilitates the assumption of nonindependence within the dyads for their attitude towards CSA as well as family communication patterns (Kenny, et al., 2006). Simple aggregate statistics (means) and t-tests were used to determine whether the differences in mean ratings were statistically different. Correlation analysis was used to determine the level of agreement (nonindependence) between parents and children within each dyad. 
The sample size consisted of 387 parent/child dyads which were surveyed in Melbourne, Australia. The 'children' in the survey were above 18 years old and were living in the same household as their parents. This was because the child's influence is strongest when they are living with the parents (Esktrom, 2007).

\section{Results}

Firstly we examined the question of the level of agreement within the dyad about whether or not the family believed that the child was influential in decision making regarding consumption of environmentally sustainable products. We assessed the level of nonindependence and found strong correlations between the parent's attitude towards children as socialisation agents and the children's attitude towards children as socialisation agents. How children influence their parents is nonindependent within the dyads. That is, the child and the parent overall have the same belief as to what extent the parents are influenced by the children when it comes to consumption of environmentally sustainable products. Thus, the perception of influence from child to parent is more alike within a family dyad than between parents and children that are not part of the dyad.

In order to test $\mathrm{H}_{\mathrm{a}}$ and $\mathrm{H} 2_{\mathrm{a}}$ a further assessment of dyadic agreement levels about attitude towards children as socialisation agents were conducted between gender compositions and marital status. This was done to assess whether greater level of influence from child to parent were connected to greater level of agreement about influence between parent and child of the same dyad. The results are shown in Table 2 .

Table 2: Dyadic Agreement regarding Attitude towards Children as Socialisation Agents

\begin{tabular}{|lcccc|}
\hline \multicolumn{1}{|c}{ Composition } & $\mathbf{N}$ & Sig. (2-tailed) & Pearson Correlation & Mean (Parent/Child) \\
\hline Whole Sample & $\mathbf{3 8 7}$ & $\mathbf{. 0 0}$ & $\mathbf{. 4 8}^{* *}$ & $\mathbf{3 . 4 2 / 3 . 2 1}$ \\
\hline Mother / Daughter & 152 & .00 & $.64^{* *}$ & $3.53 / 3.47$ \\
\hline Father / Daughter & 56 & .00 & $.43^{* *}$ & $3.66 / 3.22$ \\
\hline Father / Son & 85 & .07 & .20 & $3.15 / 2.86$ \\
\hline Mother / Son & 92 & .00 & $.43^{* *}$ & $3.33 / 3.11$ \\
\hline Two Parents fam. & 228 & .00 & $.40^{* *}$ & $3.32 / 3.07$ \\
\hline One Parent fam. & 156 & .00 & $.59^{* *}$ & $3.56 / 3.43$ \\
\hline \hline **. Correlation is significant at the 0.01 level (2-tailed). & \\
\hline
\end{tabular}

Table 2 shows a large difference depending on whether the dyad is a one parent or a two parent family. This means that agreement between parent and child about influence depends whether the family is single parent or two parents. Single parents have a much larger level of agreement with their children about how they influence them. This possibly indicates a closer relationship in single parent families since parent and child have a better understanding about how the child influences the parent. Alternatively, as suggested by Shim, Serido and Barber (2011) adolescent children are assuming more responsibility for family decisions in these families. In decisions for the family, the single parent and their child is a very close-knit decision making unit.

Large variations in the level of dyadic agreement about attitude towards children as socialisation agents when it comes to the gender of parents and children were also evident. Mothers and daughters seem to have a close relationship, while fathers and sons do not seem to agree at all. When it comes to purchasing environmentally 
sustainable products, it seems evident that 'father-son' conversations do not usually occur. Although the actual level of influence may not always be high, all other dyad compositions seem to have an understanding about how children influence their parents. $\mathrm{H} 1_{\mathrm{a}}$ and $\mathrm{H} 2_{\mathrm{a}}$ are supported.

To test $\mathrm{H}_{\mathrm{b}}$ and $\mathrm{H} 2_{\mathrm{b}}$ we compared the means between the different dyad compositions. In order to test the hypothesis we used family measures by combining the responses of parents and children within each family dyad. Independent sample ttests were conducted to test if the differences in means were statistically significant. The means and the results of the t-tests are reported in table 3 and 4 below.

Table 3: Influence of Gender and family size on Attitude towards CSA

\begin{tabular}{|l|cc|}
\hline Composition & $\mathbf{N}$ & Mean: Attitude Towards CSA \\
\hline Whole Sample & $\mathbf{3 8 7}$ & $\mathbf{3 . 3 2}$ \\
\hline Mothers / Daughter & 152 & 3.50 \\
\hline Mother / Son & 92 & 3.22 \\
\hline Fathers / Daughter & 57 & 3.45 \\
\hline Father / Son & 85 & 3.01 \\
\hline Two Parents fam. & 228 & 3.20 \\
\hline One Parent fam. & $\mathbf{1 5 8}$ & $\mathbf{3 . 5 0}$ \\
\hline
\end{tabular}

Table Error! No text of specified style in document.Error! No text of specified style in document.Error! No text of specified style in document.4: Independents Sample t-test: Impact of Gender and family size on Attitude towards CSA

\begin{tabular}{|l|c|c|c|}
\cline { 2 - 4 } \multicolumn{1}{c|}{} & \multicolumn{3}{c|}{ t-test for Equality of Means } \\
\cline { 2 - 4 } \multicolumn{1}{c|}{ Dyad Composition } & t & df & Sig. (2-tailed) \\
\hline $\begin{array}{l}\text { Mother's influence by: } \\
\text { Daughters (N 152) vs. Sons (N92) }\end{array}$ & 1.57 & 242 & .12 \\
\hline $\begin{array}{l}\text { Father's influence by: } \\
\text { Daughters (N57) vs. Sons (N85) }\end{array}$ & 2.24 & 141 & .03 \\
\hline $\begin{array}{l}\text { Daughter's influence on: } \\
\text { Father's (N57) vs. Mother's (N152) }\end{array}$ & .24 & 207 & .81 \\
\hline $\begin{array}{l}\text { Son's influence on: } \\
\text { Fathers (N85) vs. Mother's (N92) }\end{array}$ & 1.19 & 176 & .24 \\
\hline $\begin{array}{l}\text { One parent families (N158) vs. } \\
\text { Two parent families (N228) }\end{array}$ & 2.35 & 384 & .02 \\
\hline
\end{tabular}

The results indicate that two parent families are less influenced by their children than what single parents are; $\mathrm{H} 2_{b}$ is supported. Single parent family decision-making is an important consideration for social marketers with this growing segment relying on the child for expertise and knowledge. This is consistent with research that has indicated that children in single parent families have more impact than those in dual parent families.

Further, fathers are more influenced by their daughters than by their sons; $\mathrm{H} 1_{\mathrm{b}}$ is partially supported. There is no difference in influence in any of the other dyad compositions. This is an unexpected result and presents an interesting conundrum for the politically correct among us. What to do with such influence?

\section{Family communication patterns}


The final hypothesis was related to how the dyad communicated about consumer behaviour in general, and how this relates to their attitude towards children as socialisation agents for their parents. General family communication about consumer behaviour was measured on two dimensions; socio- and concept orientated communication patterns, and then divided into a fourfold measure of family communication patterns (see Figure 1, pg. 6).

The two dimensions of family communication patterns (FCP) were split into the four groups; laissez-faire, protective, pluralistic and consensual family communication. Median splits on the socio- and concept orientation dimensions were used to place the dyads into cells of the fourfold FCP typology. Assigning participants to FCP using median splits is the typical procedure in consumer socialisation studies (cf. Carlson, Walsh, Laczniak, \& Grossbart, 1994; Chan \& McNeal, 2003; Moschis \& Moore, 1979). For the socio-oriented dimension the median split was at 3.8 and for the concept-oriented dimension the median split was at 4.5. The results show that the median split gives four groups of fairly equal size. The high median in the concept oriented dimension suggests that the participants in general support a more issueoriented equal communication rather than obedience and control (socio-orientation).

Table 5: Influence of Family Communication Patterns on Attitude towards CSA

\begin{tabular}{|lcc|}
\hline FCP & $\mathbf{N}$ & Mean: Attitude Towards CSA \\
\hline Whole Sample & $\mathbf{3 8 7}$ & $\mathbf{3 . 3 2}$ \\
\hline Consensual & 105 & 3.96 \\
\hline Pluralistic & 90 & 3.39 \\
\hline Protective & 93 & 3.04 \\
\hline Laissez-Faire & $\mathbf{9 9}$ & $\mathbf{2 . 8 3}$ \\
\hline
\end{tabular}

Table 6: Independents Sample t-test: Impact of FCP on attitude towards CSA

\begin{tabular}{|c|c|c|c|}
\hline \multirow{2}{*}{$\begin{array}{l}\text { Type of FCP } \\
\text { Compared }\end{array}$} & \multicolumn{3}{|c|}{ t-test for Equality of Means } \\
\hline & $\mathbf{t}$ & df & Sig. (2-tailed) \\
\hline $\begin{array}{l}\text { Consensual / } \\
\text { Pluralistic }\end{array}$ & 3.09 & 193 & .00 \\
\hline $\begin{array}{l}\text { Consensual / } \\
\text { Protective }\end{array}$ & 5.33 & 196 & .00 \\
\hline $\begin{array}{l}\text { Consensual / } \\
\text { Laissez-Faire }\end{array}$ & 6.79 & 202 & .00 \\
\hline $\begin{array}{l}\text { Pluralistic / } \\
\text { Laissez-Faire }\end{array}$ & 5.33 & 196 & .00 \\
\hline $\begin{array}{l}\text { Pluralistic / } \\
\text { Protective }\end{array}$ & -1.92 & 181 & .06 \\
\hline $\begin{array}{l}\text { Protective / } \\
\text { Laissez-Faire }\end{array}$ & 1.37 & 190 & .17 \\
\hline
\end{tabular}

Table 5 and 6 demonstrates that the relationship between family communication and attitude towards children as socialisation agents is heavily dependent on the nature of communication in the family. This means that the parent's initial (primary) socialisation of the child has a direct impact on the child's (secondary) socialisation of the parent. In general, families that foster an open, issue based form of communication (concept-oriented) are much more likely to have a positive attitude towards children as socialisation agents than families that stress parental control (socio-oriented). 
H3 is supported; the results clearly demonstrate that a consensual communication pattern is closed related to a positive attitude towards children as socialisation agents for their parents with regards to environmentally sustainable products. This means that parents and children are most likely to exchange their knowledge about these products when the child is encouraged to take interest in the world of ideas - but to do so without disturbing the family's hierarchy of opinion. Indeed; consensual parents engage in issue-oriented communication, encourage expression of ideas, but at the same time maintain parental control, and stress the importance of considering others. Pluralistic family communication, where the focus on more centred around horizontal communication, does not relate as strongly to a positive attitude towards children as socialisation agents for their parents.

It is clear that issue-based communication in addition to maintaining family hierarchy is the best way for families to communicate in order for children to learn from their parents. On the other hand, laissez-faire communication is strongly related to children having little impact on their parents with regards to environmentally sustainable products. Protective parents that mainly focus on parental control, does not seem to relate to a positive attitude towards children as socialisation agents either.

\section{Conclusion}

Our results demonstrate that parents can be persuaded by their children and further; parents appear to accept the veracity of that persuasion. In addition, parents can, and do cede expert power to their adolescent children when it comes to consumption decisions. Social marketers seeking to engender environmentally responsible attitudes may leverage the influence of the child through education programs at school or within the locus of the child. These results show that it is feasible to generate strategies aimed at encouraging children to promote the environment when it comes to their parents.

Importantly, single parents are much more likely to be influenced by their children about environmentally sustainable products than two parent families. From a social marketing perspective, this allows us the opportunity to develop strategies targeting single-parent families that are different from the norm. Children in these families are more likely to be active decision makers, purchase products on behalf of the family and to take primacy in decisions where they have more informational power. As a consequence, adolescents can be the target of positive messaging about their capacity to influence the future; a welcome change from the many negative messages they are often in receipt of.

Gender has an important impact on whether parents learn from their children about environmentally sustainable products. Our results demonstrate that fathers are significantly more influenced by their daughters than by their sons. Also, fathers and sons do not agree with regards to child-to-parent influence. All other dyad compositions had a high level of agreement when it came to the level of influence the child had over the parent. This is very positive because it indicates an understanding within the family about the child's potential to impact the parent. By educating the child, a social marketer is also likely to reach the parent. However, we did identify communication problems with regards to father-son communication. An effective social marketing campaign targeted to families should therefore also focus on the how 
fathers and sons can learn from each other. While changing the nature of father-son communications is out of scope for social marketing, we can consider whether social marketing can create mechanisms where fathers provide their sons with permission to think differently and persuade their fathers accordingly.

Children are likely to learn about sustainable consumption at school. With this in mind, strategies for how children could influence their parents could also be implemented. However, encouraging the parents to 'listen to their children' may not be equally effective because some parents may not want this sort of advice from their children. Ekström (2007) suggested a 'boomerang effect' if the parent feels the child is telling them what to do. This may typically occur if a child tries to tell the parent to quit smoking, resulting in the parent smoking even more. Rather, parents should be taught the importance of letting their children develop their own opinions (conceptorientation), while at the same time upholding the hierarchy in the family and teach the children to have respect for others. Our results show that some parents do listen to their children. Social marketers can leverage this propensity by using communication tools that are used mostly by adolescents and encouraging their influence at home.

When developing communication plans for changing consumers' attitudes towards more sustainable consumption, it will be effective to address children and encourage them to influence their parents. Parents on the other hand, should be addressed with encouragement to foster issue based, open communication patterns within the family buy also with a focus on respect for others; consensual families are much more likely to be influenced by their children about environmentally sustainable products. Seemingly, this type of communication works best between fathers and daughters and in single parent families.

From our results, it is clear that in consensual families reciprocal consumer socialisation is more prominent, where parents and children continually learn from each other about environmentally sustainable products. Perhaps this is because consensual families encourage children to develop their own ideas, but at the same time teach them to have respect for others. Respect for others, may be related to respect for the environment - which makes the parent more prone to learn from their children with regards to sustainable consumption. This is good news for social marketers. However, we need to be cautious, as there are other types of family and what applies to one segment may not apply to all.

Apart from father-son dyads, our research also demonstrates that parents and children are in agreement about their patterns of communication and their attitude towards children as socialisation agents for their parents. For social marketers, this provides an opportunity to influence the family through influencing the child. In the area of environmental sustainability, there is some evidence to suggest children are more aware and active than their parents (Easterling, et al., 1995; Larsson, Andersson, \& Osbeck, 2010). As a consequence, this enthusiasm could potentially be harnessed by social marketing strategies enjoining children and their parents into environmentally sustainable behaviours. Although the idea of targeting children to reach the parent is not new in marketing, it does not seem to be used to a large extent when it comes to social marketing. 


\section{References}

Ahuja, R. D., Capella, L. M., \& Taylor, R. D. (1998). Child influences, attitudinal and behavioral comparisons between single parent and dual parent households in grocery shopping decisions. Journal of Marketing Theory and Practice, 6(1), 4862.

Alba, J. W., \& Hutchinson, J. W. (1987). Dimensions of Consumer Expertise. Journal of Consumer Research, 13(March), 411-454.

Anderson, W. T. (1994). Deciphering dyads: Concepts, Methods, and Controversies in Relational Research. Psychology and Marketing, 11(5), 447-456.

Ballantyne, R., Connell, S., \& Fien, J. (1998). Students as catalysts of environmental change: A framework for researching intergenerational influence through environmental education. Environmental Education Research, 4(3), 285-298.

Bandura, A. (1969). Social-Learning Theory of Identificatory Processes. In D. A. Goslin (ed.), Handbook of Socialization Theory and Research (pp. 213-262). Chicago: Rand McNally College Publishing Company.

Bandura, A. (1977). Social learning theory. Englewood Cliffs, N.J.: Prentice Hall.

Belch, M. A., Krentler, K. A., \& Willis-flurry, L. A. (2005). Teen internet mavens: influence in family decision making. Journal of Business Research, 58(5), 569575.

Berger, P. L., \& Luckmann, T. (1967). The Social Construction of Reality. London: Allen Lane the Penguin Press.

Brim, O. G. (1966). Socialization through the life cycle. In O. G. Brim \& S. Wheeler (eds.), Socialization after childhood: Two Essays (pp. 1-50). New York: John Wiley \& Sons, Inc.

Carlson, L., Walsh, A., Laczniak, R. N., \& Grossbart, S. (1994). Family communication patterns and marketplace motivations, attitudes, and behaviors of children and mothers. The Journal of Consumer Affairs, 28(1), 25-53.

Chan, K., \& McNeal, J. U. (2003). Parent-child communications about consumption and advertising in China. Journal of Consumer Marketing, 20(4), 317-334.

Chan, K., \& McNeal, J. U. (2006). Chinese children's understanding of commercial communications: A comparison of cognitive development and social learning models. Journal of Economic Psychology, 27(1), 36-56.

Chang, C.-O., Chen, S.-M., \& Somerville, T. (2003). Economic and Social Status in Household Decision-making: Evidence Relating to Extended Family Mobility. Urban Studies, 40(4), 733-746.

Chavda, H., Haley, M., \& Dunn, C. (2005). Adolescents' influence on family decisionmaking. Young Consumers, 6(3), 68-78.

Chen, Y.-C. (2008). The Influence of Family Communication Patterns on Adolescents' Decision-Making Process. Nottingham eDissertations, Nottingham University, UK.

Churchill, G. A., \& Iacobucci, D. (2005). Marketing research: methodological foundations (9 ed.). Mason, Ohio: Thomson South-Western.

Cialdini, R. (1993). Influence: the psychology of persuasion. New York: Morrow.

Cronbach, L. J. (1951). Coefficient alpha and the internal structure of tests. Psychometrika, 16(3), 297-334.

Davis, H. L. (1976). Decision Making within the Household. Journal of Consumer Research, 2(4), 241-260.

Dotson, M. J., \& Hyatt, E. M. (2000). A comparison of parents' and children's knowledge of brands and advertising slogans in the United States: implications for consumer socialization. Journal of Marketing Communications, 6(4), 219-230.

Douglas, S. P. (1983). Examining family decision making processes. Advances in Consumer Research, 10(1), 451-453. 
Easterling, D., Miller, S., \& Weinberger, N. (1995). Environmental Consumerism: A Process of Children's Socialization and Families' Resocialization. Psychology \& Marketing, 12(6), 531-550.

Ekström, K. M. (2006). Consumer Socialization Revisited. In R. W. Belk (ed.), Research in Consumer Behavior (Vol. 10, pp. 71-98). Oxford, UK: Elsevier Science Ltd.

Ekström, K. M. (2007). Parental consumer learning or 'keeping up with the children'. Journal of Consumer Behaviour, 6(4), 203-217.

Foxman, E. R., Tansuhaj, P. S., \& Ekström, K. M. (1989). Family Members' Perceptions of Adolescents' Influence in Family Decision Making. Journal of Consumer Research, 15(4), 482-491.

Frame, B., \& Newton, B. (2007). Promoting sustainability through social marketing: examples from New Zealand. International Journal of Consumer Studies, 31(6), 571-581.

Geuens, M., De Pelsmacker, P., \& Mast, G. (2003). How family structure affects parent child communication about consumption. Young Consumers, 4(2), 57-62.

Hair, J. F., Black, W. C., Babin, B. J., \& Anderson, R. E. (2010), Multivariate data analysis: a global perspective, 7 edn., Upper Saddle River, N.J.: Pearson Education.

Hahlo, G. (1999). Millennium Kids and the Post-Modern Family. Young Consumers, 1(3), $229-237$.

Jacoby, J. (1971). A Model of Multi-Brand Loyalty. Journal of Advertising Research, 11(3), 25-31.

Jinkook, L., \& Jinsook, C. (2005). Consumers' Use of Information Intermediaries and the Impact on Their Information Search Behavior in the Financial Market. Journal of Consumer Affairs, 39(1), 95-120.

John, D. R. (1999). Consumer socialization of children: A retrospective look at twentyfive years of research. Journal of Consumer Research, 26(3), 183-213.

Kenny, D. A., Kashy, D. A., \& Cook, W. L. (2006). Dyadic data analysis. New York: Guilford Press.

Lachance, M. J., Beaudoin, P., \& Robitaille, J. (2003). Adolescents' brand sensitivity in apparel: influence of three socialization agents. International Journal of Consumer Studies, 27(1), 47-57.

Larsson, B., Andersson, M., \& Osbeck, C. (2010). Bringing Environmentalism Home: Children's influence on family consumption in the Nordic Countries and beyond. Childhood, 17(1), 129-147.

Mangleburg, T. F. (1990). Children's Influence In Purchase Decisions: A Review and Critique. Advances in Consumer Research, 17(1), 813-825.

Mathur, A. (1999). Adoption of technological innovations by the elderly: a consumer socialization perspective. Journal of Marketing Management, 9(3), 21-35.

McLeod, J. M., \& Chaffee, S. H. (1972). The construction of social reality. In J. Tedeschi (ed.), The Social Influence Processes (pp. 50-59). Chicago: Aldine Atherton.

Moschis, G. P. (1987). Consumer Socialization: A Life-Cycle Perspective. Lexington, Massachusetts: Lexington Books.

Moschis, G. P., \& Churchill, G. A. (1978). Consumer Socialization: A Theoretical and Empirical Analysis. Journal of Marketing Research, 15(4), 599-609.

Moschis, G. P., \& Moore, R. L. (1979). Family communication and consumer socialization. Advances in Consumer Research, 6(1), 359-363.

Newcomb, T. M. (1953). An approach to the study of communicative acts. Psychological Review, 60(6), 393-404.

Niemi, P. M. (1988). Family interaction patterns and the development of social conceptions in the adolescent. Journal of Youth and Adolescence, 17(5), 429-444. 
Pettersson, A., Olsson, U., \& Fjellström, C. (2004). Family life in grocery stores - a study of interaction between adults and children. International Journal of Consumer Studies, 28(4), 317-328.

Quester, P., \& Lim, A. L. (2003). Product involvement/brand loyalty: is there a link? Journal of Product \& Brand Management, 12(1), 22-38.

Rappoport, A. (2005). Co-Narcissism: How We Accommodate to Narcissistic Parents. The Therapist, Retrieved 03.09, 2009, from http://www.alanrappoport.com/

Rose, G. M., Boush, D., \& Shoham, A. (2002). Family communication and children's purchasing influence: a cross-national examination. Journal of Business Research, 55(11), 867-873.

Rose, G. M., Bush, V. D., \& Kahle, L. (1998). The Influence of Family Communication Patterns on Parental Reactions toward Advertising: A Cross-National Examination. Journal of Advertising, 27(4), 71-85.

Rose, G. M., Dalakas, V., \& Kropp, F. (2003). Consumer Socialization and Parental Style Across Cultures: Findings from Australia, Greece, and India. Journal of Consumer Psychology, 13(4), 366-376.

Sexton, K. (2006). Finding Common Ground for Environmental Decisions: Public Health Principles as a Foundation for Better Choices. Human \& Ecological Risk Assessment, 12(2), 209-218.

Shim, S., Serido, J., \& Barber, B. (2011). A Consumer Way of Thinking: Linking Consumer Socialization and Consumption Motivation Perspectives to Adolescent Development. Journal of research on Adolescence, 21(1), 290-299.

Sorce, P., Loomis, L., \& Tyler, P. R. (1989). Intergenerational Influence on Consumer Decision Making. Advances in Consumer Research, 16(1), 271-275.

Szybillo, G. J., Sosanie, A.K., \& Tenenbein, A. (1979). Family member influence in household decision making. Journal of Consumer Research, 6(3), 312-316.

Taeho, Y. (2005). Parent, peer and TV influences on American teens' athletic shoes purchasing. International Journal of Sport Management and Marketing, 1(1/2), 180-189.

VandenBos, G. R. (2007). APA dictionary of psychology (1 ed.). Washington, DC: American Psychological Association.

Ward, S. (1974). Consumer Socialization. Journal of Consumer Research, 1(2), 1-14.

Watne, T. (2010). Reciprocal Consumer Socialisation. Unpublished PhD Thesis, Swinburne University of Technology, Melbourne.

Watne, T., \& Brennan, L. (2009). Secondary Consumer Socialisation of Adults. Paper presented at the Australia and New Zealand Marketing Academy (ANZMAC) conference, Monash University, Melbourne, Australia, 30 November - 03 December.

Watne, T., Lobo, A., \& Brennan, L. (2011). Children as Secondary Socialisation Agents for their Parents. Young Consumers, 12(4), Forthcoming 